\title{
Climate Change Adaptation in Acid Sulfate Landscapes
}

\author{
Chuxia Lin \\ Australian Centre for Sustainable Catchments, \\ University of Southern Queensland, Toowoomba, QLD 4350 Australia
}

Received 2012-05-31, Revised 2012-06-16; Accepted 2012-07-06

\begin{abstract}
Oxidation of sulfide minerals produces sulfuric acid and consequently creates Acid Sulfate Landscapes (ASLs), which represent one of the most degraded types of land-surface environments. Although acid sulfate-producing weathering is a naturally occurring process, it is markedly facilitated by human intervention. Mining is by far the dominant anthropogenic cause for the creation of inland acid sulfate footprints while land reclamation in coastal lowlands is the driver for the formation of coastal ASLs. The projected climate change highlights the possibility of an increase in the frequency and severity of extreme weather events such as droughts and heavy rains, which is likely to accelerate the acid generation in some circumstances and increase the frequency and magnitude of acid discharge. Sea level rise as a result of global warming will cause additional problems with the coastal ASLs. This is a review article. The following aspects are covered: (a) the overriding biogeochemical processes leading to acid sulfateproducing weathering, (b) a brief introduction to the inland acid sulfate landscapes, (c) a brief introduction to the coastal acid sulfate landscapes, (d) the likely impacts of climate change on ASLs and (e) the possible measures to combat climate change-induced environmental degradation in the identified key acid sulfate footprints. The projected climate change is like to significantly affect the acid sulfate landscapes in different ways. Appropriate management strategies and cost-effective technologies need to be developed in order to minimize the climate change-induced ecological degradation.
\end{abstract}

Keywords: Climate Change, Acid Sulfate Landscapes (ASLs), Acid Mine Drainage (AMD), Acid Sulfate Soils, Pyrite, Ecological Degradation

\section{INTRODUCTION}

The term "Acid Sulfate Landscapes" (ASLs) used in this article is referred to as land-surface environments that are affected by the oxidation of sulfide minerals. Oxidation of many metal sulfides leads to the generation of sulfuric acid and liberation of environmentally significant metals (Alpers and Blowes, 1994; Dinelli et al., 2001; Lin and Lin, 2003; Audry et al., 2005; Lee et al., 2005; Lu et al., 2011). This poses a major environmental threat in mined areas and coastal lowlands where sulfide minerals are present (Wilson and Hyne, 1997; DeNicola and Stapleton, 2002; Levings et al., 2005). The soils formed from sulfidic parent materials are known as acid sulfate soils (mine site acid sulfate soils and coastal acid sulfate soils) and the process through which the acidic water discharges from the acid sulfate soils, mine spoils and tailings is referred to as acid drainage. Acid drainage from mine sites has been traditionally termed as Acid Mine Drainage (AMD) (Johnson and Hallberg, 2005; Akcil and Koldas, 2006). More recently, the term "Acid Rock Drainage" (ARD) has also been used to cover acid drainage from naturally exposed rock formations that contain sulfide minerals (Mata et al., 2002; Miller et al., 2010).

Global-scale observations of sulfide mineral-derived acid drainage indicate that the incidences of significant environmental damage in ASLs frequently occur during and immediately after the first heavy rainfall events following prolonged dry spells (Lin et al., 2007; Macdonald et al., 2007; Nordstrom, 2009). The projected climate change highlights the possibility of increase in the frequency and severity of extreme weather events such as droughts and heavy rains (Mirza, 2003; IPCC, 
2007), which is likely to intensify the environmental damage in ASLs. The flushing of acid sulfate materials from acid sulfate soils and mine wastes will cause larger sudden increases in concentrations that will be an ever increasing danger to aquatic life with climate change (Nordstrom, 2009).

This review article covers the following aspects: (a) the overriding biogeochemical processes leading to acid sulfate-producing weathering, (b) a brief introduction to the inland acid sulfate landscapes, (c) a brief introduction to the coastal acid sulfate landscapes, (d) the likely impacts of climate change on ASLs and (e) the possible measures to combat climate change-induced environmental degradation in the identified key acid sulfate footprints.

\section{ACID SULFATE PRODUCING WEATHERING}

Oxidation of certain sulfide mineral types results in the production of acid sulfate materials. The common acid-generating sulfide minerals include pyrite $\left(\mathrm{FeS}_{2}\right)$, pyrrhotite $\left(\mathrm{Fe}_{1-\mathrm{x}} \mathrm{S}\right)$, chalcopyrite $\left(\mathrm{CuFeS}_{2}\right)$, marcasite $\left(\mathrm{FeS}_{2}\right)$, sphalerite $(\mathrm{ZnS})$ and arsenopyrite (FeAsS) (Jennings et al., 2000; Jiang et al., 2008).

Pyrite is the most abundant sulfide mineral in the Earth's surface environments (Alpers and Blowes, 1994). In a global-scale, oxidation of pyrite is the most important process leading to the formation of ASLs. The primary oxidant driving pyrite oxidation is molecular oxygen $\left(\mathrm{O}_{2}\right)$, which plays a direct role in pyrite oxidation at the initial stage of pyrite weathering under circumneutral $\mathrm{pH}$ conditions, as described by the following chemical equation:

$$
\begin{aligned}
& 2 \mathrm{FeS}_{2(\mathrm{~s})}+7 \mathrm{O}_{2(\mathrm{~g})}+2 \mathrm{H}_{2} \mathrm{O}_{(\mathrm{l})} \rightarrow 2 \mathrm{Fe}^{2+}{ }_{\text {(aq) }} \\
& +4 \mathrm{SO}_{4}{ }^{2-}{ }_{\text {(aq) }}+4 \mathrm{H}^{+}{ }_{\text {(aq) }}
\end{aligned}
$$

The aqueous ferrous ion $\left(\mathrm{Fe}^{2+}\right)$ generated from Equation 1 may be subsequently oxidized to ferric ion $\left(\mathrm{Fe}^{3+}\right)$ by molecular oxygen, as shown below:

$$
4 \mathrm{Fe}^{2+}{ }_{(\mathrm{aq})}+\mathrm{O}_{2(\mathrm{~g})}+4 \mathrm{H}^{+}{ }_{(\text {aq })} \rightarrow 4 \mathrm{Fe}^{3+}{ }_{(\mathrm{aq})}+2 \mathrm{H}_{2} \mathrm{O}_{(1)}
$$

The aqueous $\mathrm{Fe}^{3+}$ produced from Equation 2 and 3 can then hydrolyze to generate hydrogen ion $\left(\mathrm{H}^{+}\right)$and consequently cause decrease in $\mathrm{pH}$ :

$$
\mathrm{Fe}^{3+}{ }_{(\text {aq })}+3 \mathrm{H}_{2} \mathrm{O}_{(1)} \rightarrow \mathrm{Fe}(\mathrm{OH})_{3(\mathrm{~s})}+3 \mathrm{H}^{+}{ }_{\text {(aq) }}
$$

When $\mathrm{pH}$ is sufficiently low to maintain $\mathrm{Fe}^{3+}$ solubility, $\mathrm{Fe}^{3+}$ acts as a more effective oxidant for pyrite oxidation, as expressed by the following overall chemical Equation:

$$
\begin{aligned}
& \mathrm{FeS}_{2(\mathrm{~s})}+14 \mathrm{Fe}^{3+}{ }_{\text {(aq) }}+8 \mathrm{H}_{2} \mathrm{O} \rightarrow 15 \mathrm{Fe}^{2+}{ }_{\text {(aq) }} \\
& +2 \mathrm{SO}_{4}{ }^{2-}{ }_{\text {(aq) }}+16 \mathrm{H}^{+}{ }_{\text {(aq) }}
\end{aligned}
$$

Oxidation of the aqueous $\mathrm{Fe}^{2+}$ by $\mathrm{O}_{2}$ to produce $\mathrm{Fe}^{3+}$ is very slow under acidic conditions but the process can be catalyzed by iron-oxidizing bacteria (Singer and Stumm, 1970; Olson, 1991), which are commonly present in the natural environments where pyrite occurs.

Overall, the microbially mediated oxidation of pyrite can be expressed by the following general chemical Equation:

$$
\begin{aligned}
& \mathrm{FeS}_{2(\mathrm{~s})}+15 / 4 \mathrm{O}_{2(\mathrm{~g})}+7 / 2 \mathrm{H}_{2} \mathrm{O}_{(\mathrm{l})} \rightarrow \mathrm{Fe}(\mathrm{OH})_{3(\mathrm{~s})} \\
& +2 \mathrm{SO}_{4}{ }^{2-}{ }_{\text {(aq) }}+4 \mathrm{H}^{+}{ }_{(\text {aq })}
\end{aligned}
$$

Therefore, the oxidation of each mole of pyrite produces two moles of sulfuric acid and one mole of iron hydroxide upon its complete weathering.

\section{INLAND ACID SULFATE LANDSCAPES}

Inland acid sulfate landscapes are associated with near-surface geological formations that contain acidproducing sulfide minerals. Exposure of sulfidic rocks on the land surface could be part of the natural geomorphic evolution, leading to acid generation and translocation to downstream areas (Grant and Newell, 1993; Neubert et al., 2011). However, human intervention such as mining and large construction activities can dramatically facilitate these processes (Jamieson et al, 2005; Johnson and Hallberg, 2005; Nieto et al., 2007).

Mining is by far the dominant anthropogenic cause for the formation of inland ASLs. In 1989, it was roughly estimated that ca. 19,300 km of streams and rivers and ca. 72,000 ha of lakes and reservoirs worldwide had been seriously damaged by mine effluents (Johnson and Hallberg, 2005). Mining projects have been rapidly increased in the recent two decades, especially in countries experiencing rapid economic growth such as in China. Many mines in the developing countries are operated without sufficient environmental management measures in place or no environmental management measure adopted at all in the cases of illegal mining (Lin et al., 2007). The extent of AMD-induced ecological degradation could be far larger than two decades ago. 
Depending on the type of ore, the method used for mining, the abundance of sulfide minerals and the dominant type of sulfide mineral, the characteristics of acid sulfate footprints created by mining operations could vary markedly from place to place.

\subsection{Acid Sulfate Footprints Associated with Metal Ore Mining}

Many economic metal ore deposits such as iron, copper, gold, lead and zinc are associated with large amounts of pyrite, pyrrhotite and arsenopyrite. In many cases, the copper and zinc ores themselves are acidgenerating sulfide minerals. The oxidation of these sulfide minerals not only produces sulfuric acid but also mobilizes substantial amounts of heavy metals that are originally bound to these minerals. Depending on the geological conditions, the ores may be extracted by different methods, which determine the type, size and distribution of mining footprints.

Open-pit mining is a common practice for metal ore extraction. This method involves the removal of soil and rocks (overburden) overlying the ore body. The bottom of mine pits usually extends below the groundwater table. Therefore, groundwater tends to flow into the mine pit. To allow mining to take place, the water needs to be pumped out of the pit. If sulfide minerals are present and oxidized, this could cause marked off-site ecological impacts. An acidic pit lake usually forms at some point in time after mine closure (Geller et al., 2012). The acidic, metal-rich lake water can generate plumes of polluted groundwater which migrate down-gradient into the surrounding aquifers (Younger et al., 2002).

In many historical mines, the overburden materials were dumped in the areas near the mine pits. Accelerated oxidation of sulfate minerals in the waste soil/rock stockpiles results in rapid acid generation, which inhibits colonization of natural plants. The lack of vegetative cover makes the soil more easily eroded. Therefore, waste soil/rock dumps are an important source of acid mine drainage, as well as sulfide mineral-containing sediments to the downstream areas. With increased environmental concerns, safe storage of waste soils/rocks are now legally required in most countries. Usually, the sulfidic waste soil/rock materials are stored in purposebuilt storage facilities with a liner on the bottom to prevent seepage of acidic water down to the adjacent aquifers and a capping layer of good soil to allow the establishment of vegetative cover after the capacity of the overburden storage facility is used up. Acid neutralizing agents and fertilizers are frequently applied to create more favourable conditions for vegetation establishment (Brown et al., 1997; Gatzweiler et al., 2001; Bleeker et al., 2002; Xenidis et al., 2002; Maddocks et al., 2004; Ram et al., 2006; Liu et al., 2009; Padmavathiamma and Li, 2010).

Where underground mining is practiced, the volume of waste rocks is markedly reduced, especially when waste rocks are used to backfill the mine voids. During mining operations, water in the mine tunnel needs to be pumped out, which could have off-site environmental impacts. Nowadays, on-site treatment of acidic mine water is part of the routine operations in many active mines in order to meet the legal requirements. After mine closure, the abandoned underground mine workings are flooded if its elevation is below the water table. The acidic water in the abandoned underground mine workings can then become a source of contaminants to the adjacent surface water and groundwater, depending on the geomorphic and geological conditions.

Another important mine footprint is tailings dam/impoundment that is designed to contain the residues of ore processing. Mine tailings materials are usually of fine-grained and consequently have a large specific area. Sulfide mineral particles in such small sizes are usually highly reactive. In order to minimize the oxidation of sulfide minerals in the tailings dam, a layer of cover water needs to be maintained to reduce the level of dissolved oxygen in the water-sediment interface.

In some mines, mud-retaining impoundments or sedimentation ponds are also constructed to intercept the sediments and mine water from the waste soil/rock dumps, as well as the mined land surfaces. However, due to high sedimentation rate, the holding capacity of these facilities could be rapidly reduced, resulting in overflowing of acidic mine water into the downstream areas, especially during and after heavy rainfall events (Lin et al., 2007). This may be a worse scenario since the total amounts of acid and toxic materials in the dam water, after accumulation during a longer period, are much greater, as compared to direct discharge from the mine spoil stockpiles.

The most significant off-site impact of acid mine drainage is the ecological degradation of the receiving streams, lakes and estuaries (Nieto et al., 2007; Shipp and Zierenberg, 2008; Bae et al., 2010). In areas where the mines are in close proximity to human habitats, the mine water or mine water-affected stream water is used for irrigation purposes. This could cause severe contamination of soils and shallow groundwater. The edible portions of crops grown on the mine watercontaminated soils frequently have elevated concentrations of heavy metals (Lin et al., 2005), which 
could cause human health problems. Where drinking water is extracted from the contaminated shallow aquifer, the well water could also be the source of human health problems (Chen et al., 2007).

\subsection{Acid Sulfate Footprints Associated with Coal Mining}

Unlike metal ore deposits, coal strata tends to have much simpler mineralogical composition with pyrite being the only sulfide mineral present in significant amount. Consequently, AMD from coal mines frequently has relatively low levels of heavy metals although some coals may contain high concentration of arsenic and selenium (Speight, 2005). Due to the nature of sedimentary deposit, coal-borne pyrite frequently appears as microcrystals in a framboidal structure, which can be more easily weathered, as compared to large pyrite cubes encountered in hard rocks. Depending on the occurrence depth of a coal deposit and other conditions, different methods are used to extract the coal. Surface mining is usually used for coal deposit that occurs at a depth less than $50 \mathrm{~m}$. Similar to open-pit metal ore mining, open-pit coal mining also creates acid sulfate pit lakes (Radhakrishnan et al., 2011) and waste soil/rock dumps. Modern surface coal mining frequently uses non-sulfidic overburden materials to backfill the mine pits, as practiced in strip mining. This minimizes the possibility of directly exposing sulfide minerals on the land surface.

Underground mining is usually used for extracting coal from deeply occurring coal seams. This mining method tends to have minimal disturbance to the land surface but may have adverse impacts on the quality of groundwater and become a source of acid mine drainage.

Coal refuse (tailings) from the coal preparation plant usually contains elevated concentration of pyrite and thus represent a significant acid sulfate footprint associated with coal mining (Olyphant et al., 1991), especially during the earlier days when these materials were not stored properly.

\subsection{Inland Acid Sulfate Soils}

In arid and semi-arid areas that are subject to prolonged droughts, inland acid sulfate soils may develop from the dried wetlands where iron sulfides are formed and accumulated under previous anaerobic conditions (Fitzpatrick et al., 1996; Hall et al., 2006; Lamontange et al., 2006).

In a global scale, inland acid sulfate soil area does not represent a major ASL. However, in certain area such as in the outback Australia, it could have a significant impact on the local ecosystem (McCarthy et al., 2006).

\section{COASTAL ACID SULFATE LANDSCAPES}

Coastal acid sulfate landscapes occur in the areas where existing and past pyritic sediments are present. These include mangrove tidal flats, coastal salt marshes and coastal floodplains/deltas. Globally, ASS are mainly distributed in Southeast Asia and Australia with paddy rice cultivation being the predominant uses of ASS in the former (e.g., Dent and Pons, 1995; Minh et al., 1997) and sugarcane farming and cattle grazing being the important agricultural use in the latter (mainly in the Queensland and northern NSW coastal areas) (e.g., Lin and Melville, 1994; Lin et al., 1998a; Cook et al., 2000). There are about 24 million ha of coastal acid sulfate soil around the world (Sullivan, 2004). The location of coastal acid sulfate soils often coincides with high population density areas (Ljung et al., 2009). As such, coastal acid sulfate soils not only impact on ecosystems but also pose a threat to human society. It was conservatively estimated that there are over 4 million ha of ASS present along the Australia's coast. ASSderived environmental degradation is so great that the problem has been causing conflicts among different sectors of communities (White et al., 1996).

The concentration of pyrite in estuarine sediments is closely related to organic carbon content and sedimentation rate (Lin et al., 1998b). Substantial amounts of pyrite (up to $10 \%$ ) can be accumulated in mangrove sediments in locations with low sedimentation rate (e.g., in Fiji Islands, unpublished data). In contrast, in rapidly expanding deltaic areas with high sedimentation rate, the concentration of pyrite in the sediments is generally very low (Lin and Melville, 1994). Like coal strata, pyrite in estuarine sediments usually appears as microcrystals in a framboidal structure and therefore is subject to rapid oxidation when exposed to atmosphere.

The distribution of coastal acid sulfate soils coincides with the estuarine areas that attract human settlement. Human activities involving excavation of pyritic estuarine sediments such as road construction, urban development and fish pond farming could expose pyritic sediments on the land surface. This causes acceleration of pyrite oxidation and therefore creates acid sulfate footprints. While pyrite oxidation in coastal floodplain may take place as a naturally occurring process in certain physiographic settings, agricultural practice could dramatically intensify the process (Lin and Melville, 1993; 1994). 
In particular, sugarcane farming requires intensive land drainage to allow sugarcane plants to grow. This, combined with the floodgate control measures to prevent the brackish/saline estuarine water from penetrating into the field drains, leads to lowering of watertable in the ASS-containing floodplains and conseqiently induces/enhances pyrite oxidation in the subsoil layers to produce sulfuric acid. The discharge of acid sulfate materials from sugarcane acid sulfate soils into the adjacent estuarine waterways during flood events acidifies the estuarine water and causes damage to the aquatic ecosystems (Lin et al., 2004; Macdonald et al., 2004).

\section{LIKELY IMPACTS OF CLIMATE CHANGE AND POSSIBLE RESPONSE MEASURES}

Acid sulfate landscapes are fragile ecosystems that are subject to further environmental damage under a changing climate. The increased temperature as well as more frequent and severe droughts and floods will have complex impacts on ecological processes in ASLs. It is not intended in this presentation to cover all possible scenarios that are likely to be encountered in a more variable climate. Instead, some key ASLs are identified and discussed below.

\subsection{Mine Pit Lakes}

Sulfide minerals exposed on the pit walls are a major source of acid and metals upon oxidation. Since the oxidation rate of sulfide minerals tends to increase with increasing temperature (Schoonen et al., 2000), acid generation is likely to be enhanced under climate change in some circumstances. Climate is the single most important factor affecting the hydrological processes associated with a mine pit lake (Castendyk and Eary, 2009). Increased precipitation is likely to cause rise in the lake water level, which poses a risk of contaminating surface water and shallow groundwater.

For mine pit lakes with a high risk of causing offsite environmental impacts, it may be necessary to adopt appropriate remediation methods for minimizing acid generation from the pit walls and detoxifying the lake water. A few methods for mine pit lake remediation have been proposed (Castendyk and Eary, 2009). The rehabilitation efforts can also make beneficial utilization of pit lakes possible (Castendyk and Eary, 2009). This is particularly relevant to the dryland areas where water resources are scarce (Kumar et al., 2009).

\subsection{Underwater-Stored Mine Tailings}

In practice, underwater storage methods have been used for disposal of mine tailings that are potentially acid-producing. Tailings Storage Facilities (TSFs) are designed to contain and keep the tailings materials under a layer of water in order to minimize contacts of sulfide minerals with oxygen. However, the engineering design of many TSFs in existing mines might not take into account the potential effects of climate change. It is likely that during future prolonged drought events, the strong evaporation rate will result in a thinner than designed layer of overlying water in the TSFs or even temporary drying out of the TSFs, leading to enhanced oxidation of sulfide minerals contained in the TSFs.

Measures to counteract drought-induced oxidation of sulfide minerals in TSFs could include methods that can be used to avoid the occurrence of massive oxidation of sulfide minerals prior to water level re-rise or reinundation of the TSF. Possible options are:

- No action if the dry interval is not sufficiently long to allow the development of massive microbially catalyzed oxidation of sulfide minerals and

- Application of chemical agents to impede oxidation of sulfide minerals

It was proposed that sodium oleate and phosphates be used to inhibit pyrite oxidation by passivating the mineral surfaces (Nyavor and Egiebor, 1995; Jiang et al., 2000). However, these techniques may be more suitable for treating materials with a high proportion of sulfide minerals such as sulfide ore concentrate. Application of such methods to tailings that contain a relatively small proportion of sulfide minerals is probably not cost-effective.

Bactericides have also been used to inhibit the growth of iron and sulfide-oxidizing bacteria that play an important role in microbially-enhanced oxidation of sulfide minerals (Rastogi, 1996). This method only has short-term effects on suppressing the microbial activities (Johnson and Hallberg, 2005). Nevertheless, for temporary control of the growth of iron and sulfide-oxidizing bacteria, as required in the current circumstances, the anti-bacteria method may be appropriate.

Another potential method for impeding oxidation of sulfide minerals is to top-dress acid neutralizing materials on the drying tailings materials to halt $\mathrm{pH}$ drop (Mylona et al., 2000; Mata et al., 2002). This reduces the level of aqueous $\mathrm{Fe}^{3+}$ that triggers catalyzed oxidation of sulfide minerals (Moses et al., 1987; Rimstidt and Newcomb, 1993; Janzen et al., 2000). 
The fundamental knowledge that is required for evaluation of these options includes:

- How long does it take to create a sufficiently acidic $\mathrm{pH}$ by abiotic oxidation of sulfide minerals to allow microbially-catalyzed oxidation to take place when no actions are taken?

- Can other oxidants rather than molecular oxygen e.g., rainwater-borne $\mathrm{H}_{2} \mathrm{O}_{2}$ play roles in the oxidation of sulfide minerals?

- What are the effects of bactericides or added acidneutralizing materials on preventing the tailings from acidification?

These are among the research issues that need to be addressed in order to develop cost-effective measures for climate change adaptation.

\subsection{Sulfidic Mine Spoils}

For surface mining, overburden materials (mine spoils) are usually disposed of on land surfaces. In mines where environmental management plan is implemented, mine spoils are usually stored in a dedicated storage facility with a layer of sealing materials (or capping materials) to minimize the penetration of air and water into the mine spoils. However, cracking of sealing layers could occur in areas experiencing acute dry and wet seasons (Johnson and Hallberg, 2005). This is likely to be intensified with climate change, potentially initiating oxidation of sulfide minerals in the originally sealed mine spoil storage facilities.

Where no environmental management plan is in place, mine spoils are often stockpiled on the land surfaces without any treatment. This is common in historical mines and many current mines especially in the developing countries (Sracek et al, 2006; Lu et al., 2010). Consequently, the sulfide minerals in mine waste stockpiles are subject to rapid oxidation and acid production. These acidic, metal-rich mine spoil stockpiles act as major sources of AMD. Given the practical difficulties entailed in inhibiting the formation of AMD at sources, treatment of mine water using either active or passive systems has been the major counteracting measures for AMD remediation in the developed world (Johnson and Hallberg, 2005; Gazea et al., 1996; Sheoran and Sheoran, 2006; Kleiv and Thornhill, 2008) while in many developing countries, acidic mine water is directly discharged into streams (Naicker et al., 2003; Lin et al., 2007). With climate change, the volume of mine water and loadings of acids and metals during extreme flood events may exceed the designed capacity of mine water treatment facilities, resulting in the entry of untreated mine water into downstream areas. For mines without mine water treatment facilities, more severe environmental damage is expected.

To minimize the climate change-induced further environmental damage in this type of ASLs, a "source control" approach needs to be adopted. In-situ acid neutralization of the acidic topsoils for vegetation establishment has been a major research effort for rehabilitation of exposed mine spoils in recent decades (Brown et al., 1997; Gatzweiler et al., 2001; Bleeker et al., 2002; Xenidis et al., 2002; Maddocks et al., 2004; Ram et al., 2006; Liu et al., 2009; Padmavathiamma and $\mathrm{Li}, 2010)$. However, there has so far been limited success in large-scale application of such technologies. There has been insufficient in-depth research conducted to unveil the biogeochemical processes accompanied with various remediation methods.

The research aspects that need to be addressed in order to improve the fundamental understanding of these biogeochemical processes may include:

- Mechanisms and kinetics of acid neutralization, particularly decomposition of jarosites, deprotonation of variably-charged colloids and desorption of exchangeable aluminium under alkaline conditions;

- Evolution of iron/sulfide-oxidizing microbial community as $\mathrm{pH}$ increase during acid neutralization of the mine spoils; and

- Potential roles of neutrophilic iron-oxidizing bacteria in oxidation of sulfide minerals

\subsection{Coastal Acid Sulfate Landscapes}

Perhaps the most vulnerable coastal acid sulfate footprints are among those containing pyritic soil materials that are directly exposed on the land surfaces such as road base, fishpond bunds and other construction sites as a result of land excavation activities. For such areas, complete neutralization of the acidity is necessary to prevent future environmental damage to be induced by climate change. For broadacre agricultural lands, it is economically unfeasible to completely neutralize the acidity in the soils. Therefore, alternative strategies need to be developed.

Among various modes of agricultural uses, sugarcane farming appears to be the one that is most sensitive to the climate change. The acidity in many acid sulfate soils under sugarcane production is in dynamic equilibrium except during drought spells, which accelerate pyrite oxidation and consequently acid generation in the soil profiles. The newly produced acid materials are ready to be exported to estuarine aquatic 
systems during major flood events following heavy rains. The potential increases in the length and frequency of droughts, as well as extreme rainfall events are expected to have significant impacts on the sugarcane production and estuarine ecosystems due to the possible increase in acid production rate in acid sulfate sugarcane soils and more frequent acid flush into the adjacent estuarine waterways.

In addition, the elevation of many coastal acid sulfate soils is either slightly higher or below the sea level. In a longer term, the projected sea level rise as a result of global warming could eventually make the sugarcane farming economically unviable due to the high costs associated with the additional engineering work to maintain a low watertable in the soils. To develop appropriate strategies and cost-effective methods for adapting to the possible environmental changes due to climate variability, the following measures are considered:

- Change from deep drainage system to shallow drainage system, coupled with alternative cropping system may be an option for climate change adaptation in this type of ASLs. This alternative water management strategy will slow down watertable lowering during extended dry spells and consequently reduce acid generation rate

- Trash retention: To change pre-harvest sugarcane burning to green harvesting with at least $50 \%$ of sugarcane trash being retained in the field. Methods can be developed to optimise the conditions for rapid decomposition of the sugarcane residues, which will create a healthy topsoil layer and also raise the elevation of the land

- $\quad$ Raised bed: use single row spaces and plant the crop at ground level, followed by soil mounding over the top of the cane sets. This will increase the thickness of unsaturated topsoil layer and also reduce nitrous gas emission, through selected compaction of interspaces and trash retention

- Slot drainage and in-drain acid neutralization: to accelerate removal of surface water during high rainfall events and following flooding and eliminate toxic materials in the drain water before discharging into estuarine waterways

- Introduction of water- and acid-tolerant sugarcane cultivars to allow sugarcane production in the acid sulfate soils with relatively high watertable conditions, as to be caused by sea level rise and increases in major rain events

\section{CONCLUSION}

The projected climate change is like to significantly affect the acid sulfate landscapes in different ways.
Increase in the frequency and severity of extreme weather events such as droughts and heavy rains will accelerate acid generation in some circumstances and increase the frequency and magnitude of acid discharge from acid sulfate footprints into the surrounding areas, causing further damage to the already fragile ecosystems. Appropriate management strategies and cost-effective technologies need to be developed in order to minimize the climate change-induced ecological degradation.

\section{REFERENCES}

Akcil, A. and S. Koldas, 2006. Acid Mine Drainage (AMD): Causes, treatment and case studies. J. Cleaner Produ., 14: 1139-1145. DOI: 10.1016/j.jclepro.2004.09.006

Alpers, C.N. and D.W. Blowes, 1994. Environmental Geochemistry of Sulfide Oxidation. 1st Edn., American Chemical Society, Washington DC, ISBN-10: 0841227721, pp: 681.

Audry, S., G. Blanc and J. Schafer, 2005. The impact of sulphide oxidation on dissolved metal $(\mathrm{Cd}, \mathrm{Zn}, \mathrm{Cu}$, $\mathrm{Cr}, \mathrm{Co}, \mathrm{Ni}, \mathrm{U}$ ) inputs into the Lot-Garonne fluvial system (France). Appl. Geochem., 20: 919-931. DOI: 10.1016/j.apgeochem.2005.01.006

Bae, D.Y., H.K. Kumar, J.H. Han, J.Y. Kim, K.W. Kim, Y.H. Kwon and K.G. An, 2010. Integrative ecological health assessments of an acid mine stream and in situ pilot tests for wastewater treatments. Ecol. Eng., 36: 653-663. DOI: 10.1016/j.ecoleng.2009.11.027

Bleeker, P.M., A.G.L. Assuncao, P.M. Teiga, T. de Koe and J.A.C. Verkleij, 2002. Revegetation of the acidic, As contaminated Jales mine spoil tips using a combination of spoil amendments and tolerant grasses. Sci. Tot. Environ., 300: 1-13. DOI: 10.1016/S0048-9697(02)00081-5

Brown, T.H., A.E. Bland and J.M. Wheeldon, 1997. Pressurized fluidized bed combustion ash 2. Soil and mine spoil amendment use options. Fuel, 76: 741748. DOI: 10.1016/S0016-2361(97)00003-3

Castendyk, D.N. and L.E. Eary, 2009. Mine pit lakes: characteristics, predictive modeling and sustainability. SME, Colorado, ISBN-13: 9780873353052, pp: 316.

Chen, A., C. Lin, W. Lu, Y. Wu, Y. Ma, J. Li and L. Zhu, 2007. Well water contaminated by acidic mine water from the Dabaoshan Mine, South China: Chemistry and toxicity. Chemosphere, 70: 248-255. DOI: $10.1016 /$ j.chemosphere.2007.06.041 
Cook, F.J, W. Hicks, E.A Gardner, G.D Carlin and D.W. Froggatt, 2000. Export of acidity in drainage water from acid sulphate soils. Mar. Pollut. Bullet., 41: 319-326. DOI: 10.1016/S0025-326X(00)00138-7

DeNicola, D.M. and M.G. Stapleton, 2002. Impact of acid mine drainage on benthic communities in streams: The relative roles of substratum Vs. aqueous effects. Environm. Pollut., 119: 303-315. DOI: $10.1016 / \mathrm{S} 0269-7491(02) 00106-9$

Dent, D.L. and L.J. Pons, 1995. A world perspective on acid sulphate soils. Geoderma, 67: 263-276. DOI: 10.1016/0016-7061(95)00013-E

Dinelli, E., F. Lucchini, M. Fabbri and G. Cortecci, 2001. Metal distribution and environmental problems related to sulfide oxidation in the Libiola copper mine area (Ligurian Apennines, Italy). J. Geochem. Explor., 74: 141-152. DOI: 10.1016/S0375-6742(01)00180-7

Fitzpatrick, R.W., E. Fritsch and P.G. Self, 1996. Interpretation of soil features produced by ancient and modern processes in degraded landscapes: V. Development of saline sulfidic features in non-tidal seepage areas. Geoderma, 69: 1-29. DOI: 10.1016/0016-7061(95)00046-1

Gatzweiler, R., S. Jahn, G. Neubert and M. Paul, 2001. Cover design for radioactive and AMD-producing mine waste in the Ronneburg area, Eastern Thuringia. Waste Manage., 21: 175-184. DOI: 10.1016/S0956-053X(00)00060-X

Gazea, B., K. Adam, A. Kontopoulos, 1996. A review of passive systems for the treatment of acid mine drainage. Miner. Eng., 9: 23-42. DOI: 10.1016/0892-6875(95)00129-8

Geller, W., M. Schultze, R. Kleinmann and C. Wolkersdorfer, 2012. Acidic Pit Lakes: The Legacy of Coal and Metal Surface Mines. 1st Edn., Springer, Verlag, ISBN-10: 3642293832, pp: 408.

Hall, K.C., D.S. Baldwin, G.N. Rees and A.J. Richardson, 2006. Distribution of inland wetlands with sulfidic sediments in the Murray-Darling Basin, Australia. Sci. Tot. Environ., 370: 235-244. DOI: 10.1016/j.scitotenv.2006.07.019

Jamieson, H.E., C. Robinson, C.N. Alpers, R.B. McCleskey and D.K Nordstrom et al., 2005. Major and trace element composition of copiapite-group minerals and coexisting water from the Richmond mine, Iron Mountain, California. Chem. Geol., 215: 387-405. DOI: 10.1016/j.chemgeo.2004.10.001
Janzen, M.P., R.V. Nicholson and J.M. Scharer, 2000. Pyrrhotite reaction kinetics: Reaction rates for oxidation by oxygen, ferric iron and for nonoxidative dissolution. Geochim. Cosmochim. Ac., 64: 1511-1522. DOI: 10.1016/S00167037(99)00421-4

Jennings, S.R., D.J. Dollhopf and W.P. Inskeep, 2000. Acid production from sulfide minerals using hydrogen peroxide weathering. Appl. Geochem., 15: 235-243. DOI: 10.1016/S0883-2927(99)00041-4

Jiang, C.L., X.H. Wang and B.K. Parekh, 2000. Effect of sodium oleate on inhibiting pyrite oxidation. Int. J. Miner. Process., 58: 305-318. DOI: 10.1016/S03017516(99)00045-9

Jiang, T., Q. Li, Y.B. Yang, G.H. Li and G.Z. Qiu, 2008. Bio-oxidation of arsenopyrite. Trans. Nonfe. Metals Soc. China, 18: 1433-1438. DOI: 10.1016/S10036326(09)60021-2

Johnson, D.B. and K.B. Hallberg, 2005. Acid mine drainage remediation options: A review. Sci. Tot. Environ., 338: 3-14. DOI: 10.1016/j.scitotenv.2004.09.002

Kleiv, R.A. and M. Thornhill, 2008. Predicting the neutralisation of acid mine drainage in anoxic olivine drains. Miner. Eng., 21: 279-287. DOI: 10.1016/j.mineng.2007.10.005

Grant, D.B. and J.M. Newell, 1993. Geological Fieldwork, 1992. 1st Edn., Ministry of Energy, Victoria, pp: 553.

Kumar, R.N., C.D. McCullough and M.A. Lund, 2009. Water resources in Australian mine pit lakes. Mining Technol., 15: 247-252.

Lamontange, S., W.S. Hicks, R.W. Fitzpatrick and S. Rogers, 2006. Sulfidic materials in dryland river wetlands. Mar. Freshwater Res., 57: 775-788. DOI: 10.1071/MF06057

Lee, P.K, M.J. Kang, S.H. Choi and J.C. Touray, 2005. Sulfide oxidation and the natural attenuation of arsenic and trace metals in the waste rocks of the abandoned Seobo tungsten mine. Korea, Appl. Geochem., 20: 1687-1703. DOI: 10.1016/j.apgeochem.2005.04.017

Levings, C.D., D.E. Varela, N.M. Mehlenbacher, K.L. Barry and G.E. Piercey et al., 2005. Effect of an acid mine drainage effluent on phytoplankton biomass and primary production at Britannia Beach, Howe Sound, British Columbia. Mar. Pollut. Bull., 50: 1585-1594. DOI: 10.1016/j.marpolbul.2005.06.032

Lin, C. and J. Lin, 2003. Heavy metals in a sulfidic minespoil: Fractions and column leaching. Pedosphere, 13: 75-80. 
Lin, C., W. Lu and Y. Wu, 2005. Agricultural soils irrigated with acidic mine water: Acidity, heavy metals, and crop contamination. Australian J. Soil Res., 43: 819-826. DOI: 10.1071/sr04148

Lin, C. and M.D. Melville, 1993. Control of soil acidification by fluvial sedimentation in an estuarine floodplain, eastern Australia. Sediment. Geol., 85: 271-284. DOI: 10.1016/0037-0738(93)90088-M

Lin, C. and M.D. Melville, 1994. Acid sulphate soillandscape relationships in the Pearl River Delta, southern China. CATENA, 22: 105-120. DOI: 10.1016/0341-8162(94)90020-5

Lin, C., M.D. Melville, M.M. Islam, B.P. Wilson and X. Yang et al., 1998a. Chemical controls on acid discharges from acid sulfate soils under sugarcane cropping in an eastern Australian estuarine floodplain. Environ. Pollut., 103: 269-276. DOI: 10.1016/S0269-7491(98)00106-7

Lin, C., M.D. Melville, I. White, B.P. Wilson and D.Yu, 1998b. Sedimentary environment and acid potential of the pyritic sediments in a sand barrier estuarine system, eastern Australia. Geochem. J., 32: 91-101.

Lin, C., M. Wood, P. Haskins, T. Ryffel and J. Lin, 2004. Controls on water acidification and deoxygenation in an estuarine waterway, eastern Australia. Estuar., Coast. Shelf Sci., 61: 55-63.

Lin, C., Y. Wu, W. Lu, A. Chen and Y. Liu, 2007. Water chemistry and ecotoxicity of an acid mine drainageaffected stream in subtropical China during a major flood event. J. Hazard. Mater., 142: 199-207. DOI: 10.1016/j.jhazmat.2006.08.006

Liu, Y., C. Lin, Y. Ma, W. Lu and Y. Wu et al., 2009. Toxic effects of two acid sulfate soils from the Dabaoshan Mine on Corymbia citriodora var.variegata and Daphnia carinata. J. Hazard. Mater., 166: 1162-1168. DOI: 10.1016/j.jhazmat.2008.12.017

Ljung, K., F. Maley, A. Cook and P. Weinstein, 2009. Acid sulfate soils and human health--a millennium ecosystem assessment. Environ. Int., 35: 1234-1242. PMID: 19647876

Lu, W., C. Lin, Y. Ma, S. Huang and C. Si et al., 2010. Characteristics and potential environmental consequence of weathered materials in the surface layer of a spontaneously combusting mine spoil stockpile. Appl. Geochem., 25: 496-501. DOI: 10.1016/j.apgeochem.2010.01.004

Lu, W., Y. Ma and C. Lin, 2011. Status of aluminium in environmental compartments contaminated by acidic mine water. J. Hazard. Mater., 189: 700-709. DOI: 10.1016/j.jhazmat.2011.03.018
Macdonald, B.C.T., J. Smith, A.F. Keene, M. Tunks and A. Kinsela et al., 2004. Impacts of runoff from sulfuric soils on sediment chemistry in an estuarine lake. Sci. Tot. Environ., 329: 115-130. DOI: 10.1016/j.scitotenv.2004.02.016

Macdonald, B.C.T., I. White, M.E. Astrom, A.F. Keene and M.D. Melville et al., 2007. Discharge of weathering products from acid sulfate soils after a rainfall event, Tweed River, eastern Australia. Appl. Geochem., 22: 2695-2705. DOI: 10.1016/j.apgeochem.2007.07.004

Maddocks, G., C. Lin and D. McConchie, 2004. Effects of Bauxsol and biosolids on soil conditions of acidgenerating mine spoil for plant growth. Environ. Pollut., 127: 157-167. PMID: 14568715

Mata, Y.N., F. Gonzalez, A. Ballester, M.L. Blazquez and J.A. Munoz, 2002. Inhibition of acid rock drainage from uranium ore waste using a conventional neutralization and precipitation treatment. Miner. Eng., 15: 1141-1150. DOI: 10.1016/S0892-6875(02)00212-1

McCarthy, B., A. Conalin, P. D'Santos and D. Baldwin, 2006. Acidification, salinization and fish kills at an inland wetland in south-eastern Australia following partial drying. Ecol. Manage. Restor., 7: 218-223. DOI: 10.1111/j.1442-8903.2006.312_1.X

Miller, S.D., W.S. Stewart, Y. Rusdinar, R.E. Schumann and J.M. Ciccarelli et al., 2010. Methods for estimation of long-term non-carbonate neutralisation of acid rock drainage. Sci. Tot. Environ., 408: 21292135. DOI: $10.1016 /$ j.scitotenv.2010.01.011

Minh, L.Q., T.P. Tuong, M.E.F. van Mensvoort and J. Bouma, 1997. Tillage and water management for riceland productivity in acid sulfate soils of the Mekong delta, Vietnam. Soil Tillage Res., 42: 1-14. DOI: 10.1016/S0167-1987(97)00004-4

Mirza, M.M.Q., 2003. Climate change and extreme weather events: Can developing countries adapt? Climate Policy, 3: 233-248. DOI: 10.1016/S14693062(03)00052-4

Moses, C.O., D.K. Nordstrom, J.S. Herman and A.L. Mills, 1987. Aqueous pyrite oxidation by dissolved oxygen and by ferric iron. Geochim. Cosmochim. Ac., 51: 1561-1571. DOI: 10.1016/00167037(87)90337-1

Mylona, E., A. Xenidis, I. Paspaliaris, 2000. Inhibition of acid generation from sulphidic wastes by the addition of small amounts of limestone. Miner. Eng., 13: $1161-1175 . \quad$ DOI: $10.1016 /$ S08926875(00)00099-6 
Naicker, K., E. Cukrowska and T.S. McCarthy, 2003. Acid mine drainage arising from gold mining activity in Johannesburg, South Africa and environs. Environm. Pollut., 122: 29-40. DOI: 10.1016/S0269-7491(02)00281-6

Neubert, J.T., J.P. Kurtz, D.J. Bove and M.A. Sares, 2011. Natural Acid Rock Drainage: Associated with Hydrothermally Altered Terrane in Colorado. 1st Edn., Colorado Geological Survey, Denver, Colorado, pp: 114.

Nieto, J.M., A.M. Sarmiento, M. Olías, C.R. Canovas and I. Riba et al., 2007. Acid mine drainage pollution in the tinto and odiel rivers (Iberian Pyrite Belt, SW Spain) and bioavailability of the transported metals to the huelva estuary. Environ. Int., 33: 445-455. DOI: 10.1016/j.envint.2006.11.010

Nordstrom, D.K., 2009. Acid rock drainage and climate change. J. Geochem. Explor., 100: 97-104. DOI: 10.1016/j.gexplo.2008.08.002

Nyavor, K. and N.O. Egiebor, 1995. Control of pyrite oxidation by phosphate coating. Sci. Tot. Environ., 162: 225-237. DOI: 10.1016/0048-9697(95)04467-F

Olson, G.J., 1991. Rate of pyrite bioleaching by Thiobacillus ferrooxidans: Results of an interlaboratory comparison. Appl. Environ. Microbiol., 57: 642-644.

Olyphant, G.A., E.R. Bayless and D. Harper, 1991. Seasonal and weather-related controls on solute concentrations and acid drainage from a pyritic coalrefuse deposit in southwestern Indiana, U.S.A. J. Contam. Hydrol., 7: 219-236. DOI: 10.1016/01697722(91)90029-Z

Padmavathiamma, P.K. and L.Y. Li, 2010. Phytoavailability and fractionation of lead and manganese in a contaminated soil after application of three amendments. Bioresour. Technol., 101: 5667-5676. DOI: 10.1016/j.biortech.2010.01.149

Ram, L.C., N.K. Srivastava, R.C. Tripathi, S.K. Jha and A.K. Sinha et al., 2006. Management of mine spoil for crop productivity with lignite fly ash and biological amendments. J. Environ. Manage., 79: 173-187. DOI: 10.1016/j.jenvman.2005.06.008

Radhakrishnan, N.K., C.D. McCullough, M.A. Lund and S.A. Larranaga1, 2011. Evaluating the factors limiting algal biomass in acidic pit lakes of the collie lake district, Western Australia. Proceddings of the 11th International Mine Water Association Congress, Mine Water-Managing the Challenges, (MWMC' 11), Aachen, Germany, pp: 523-528.
Rastogi, V., 1996. Water quality and reclamation management in mining using bactericides. Int. J. Rock Mechanics Mining Sci. Geomech. Abs., 33: A377-A378. DOI: 10.1016/S0148-9062(97)87579-1

Rimstidt, J.D. and W.D. Newcomb, 1993. Measurement and analysis of rate data: The rate of reaction of ferric iron with pyrite. Geochim. Cosmochim. Ac., 57: 1919-1934. DOI: 10.1016/0016-7037(93)90084-A

Shipp, W.G. and R.A. Zierenberg, 2008. Pathways of acid mine drainage to clear lake: Implications for mercury cycling. Ecol. Appl., 18: A29-A54. DOI: 10.1890/06-1497.1

Singer, P.C. and W. Stumm, 1970. Acidic mine drainage: the rate-determining step. Sci., 167: 1121-1123.

Sheoran, A.S., V. Sheoran, 2006. Heavy metal removal mechanism of acid mine drainage in wetlands: A critical review. Miner. Eng., 19: 105-116. DOI: 10.1016/j.mineng.2005.08.006

Schoonen, M., A. Elsetinow, M. Borda and D. Strongin, 2000. Effect of temperature and illumination on pyrite oxidation between $\mathrm{pH} 2$ and 6 . Geochem. Trans., 1: 23-23. DOI: 10.1039/b004044

Speight, J.G., 2005. Handbook of coal analysis. 1st Edn., John Wiley and Sons, Inc., Hoboken, ISBN-10: 0471522732, pp: 222.

Sracek, O., P. Gelinas, R. Lefebvre and R.V. Nicholson, 2006. Comparison of methods for the estimation of pyrite oxidation rate in a waste rock pile at Mine Doyon site, Quebec, Canada. J. Geochem. Explor., 91: 99-109. DOI: 10.1016/j.gexplo.2006.03.002

Sullivan, L., 2004. Preface: Sustainable management of acid sulfate soil. Aust. J. Soil Res.,

IPCC, 2007. IPCC Fourth Assessment Report: Climate Change 2007. Intergovernmental Panel Clim. Chan., 4: 213-252.

White, I., J. Sammut, M.D. Melville, P. van Oploo and B.P. Wilson, 1996. Acid Sulfate Soils: Facing the Challenges. 1st Edn., Earth Foundation Australia, ISBN-10: 0958698309, pp: 55.

Wilson, S.P. and R.V. Hyne, 1997. Toxicity of acidsulfate soil leachate and aluminum to embryos of the Sydney rock oyster. Ecotox. Environm. Safe., 37: 30-36. DOI: 10.1006/eesa.1996.1514

Xenidis, A., E. Mylona and I. Paspaliaris, 2002. Potential use of lignite fly ash for the control of acid generation from sulphidic wastes. Waste Manage., 22: 631-641. DOI: 10.1016/S0956-053X(01)00053-8

Younger, P.L., S.A. Banwart and R.S. Hedin, 2002. Mine Water: Hydrology, Pollution, Remediation. 1st Edn., Springer, Dordrecht, ISBN-10: 140200138X, pp: 442. 